\title{
Effect of Supplemental Irrigation and Graded Levels of Nitrogen on Cotton Yield and Quality
}

\author{
Ruixiu Sui ${ }^{1}$, Richard K. Byler ${ }^{2}$, Daniel K. Fisher ${ }^{1}$, Edward M. Barnes ${ }^{3}$ \& Christopher D. Delhom ${ }^{4}$ \\ ${ }^{1}$ USDA-ARS Crop Production Systems Research Unit, Stoneville, MS 38776, USA \\ ${ }^{2}$ USDA-ARS Cotton Ginning Research Unit, Stoneville, MS 38776, USA \\ ${ }^{3}$ Cotton Incorporated, Cary, NC 27513, USA \\ ${ }^{4}$ USDA-ARS Cotton Structure and Quality Research Unit, New Orleans, LA 70124 USA \\ Correspondence: Ruixiu Sui, USDA-ARS Crop Production Systems Research Unit, Stoneville, MS 38776, USA. \\ Tel: 662-686-5382. E-mail: ruixiu.sui@ars.usda.gov
}

\author{
Received: November 19, 2013 Accepted: December 16, 2013 Online Published: January 15, 2014 \\ doi:10.5539/jas.v6n2p119 \\ URL: http://dx.doi.org/10.5539/jas.v6n2p119
}

\begin{abstract}
Effects of supplemental irrigation and graded levels of nitrogen $(\mathrm{N})$ on cotton yield and fiber quality were investigated in the Mississippi Delta in 2011 and 2012. Cotton was planted in 48 experimental plots with irrigation as main treatment unit and $\mathrm{N}$ application rate $\left(0,39,67,101,135\right.$, and $\left.168 \mathrm{~kg} \mathrm{ha}^{-1}\right)$ as subunit. Supplemental irrigation was conducted based on soil-water sensor measurements. Cotton yield was determined using a boll buggy equipped with load cells. Cotton samples were collected and ginned, and the fiber quality was evaluated. Statistical analyses on the effects of irrigation and leaf $\mathrm{N}$ on the yield and fiber quality indicated that compared with non-irrigated cotton, the irrigated cotton increased seed cotton yield by $14 \%$. Leaf $\mathrm{N}$ content varied in a range of $3.27 \%$ to $5.86 \%$ with an average of $4.34 \%$. Leaf $\mathrm{N}$ of irrigated plants was $9.0 \%$ and $3.6 \%$ higher than that of the non-irrigated plants in 2011 and 2012, respectively. Soil water stress had a negative effect on N uptake of cotton plants. Yield showed a positive linear correlation with leaf $\mathrm{N}$ content in both irrigated and non-irrigated plots. Irrigation improved fiber quality, including all fiber length parameters. Upper half mean length (UHML) of cotton fiber in irrigated treatment was $2.7 \%$ and $1.8 \%$ greater than that in the non-irrigated treatment in 2011 and 2012, respectively. Micronaire decreased, and neps and yellowness increased with the increase of leaf $\mathrm{N}$ under irrigated and non-irrigated conditions. Excessive application of $\mathrm{N}$ would not be beneficial to fiber quality and could possibly create negative impact on some properties of cotton fibers.
\end{abstract}

Keywords: irrigation, cotton, fiber quality, yield, nitrogen

\section{Introduction}

Average annual rainfall in the Mid-South U.S. is around $140 \mathrm{~cm}$ (55"). However, heavy precipitation events in the summer generate high runoff. It makes actual amount of rainfall entering into the soil for plant use is small and not sufficient for the growth of crops like cotton, corn, and soybean in this region. Additionally, the runoff can cause nutrient loss from cropland, which has become an environmental issue (Bakhsh, Kanwar, Bailey, Cambardella, Karlen, \& Colvin, 2002; Potter, Atwood, \& Goss, 2001). Uncertainty in the amount and timing of precipitation is one of the most serious risks to producers in the Mid-South. In recent years, producers have become increasingly reliant on supplemental irrigation to ensure adequate yields and reduce risks of production. Therefore, research to optimize crop water and nutrient management is necessary.

Cotton (Gossypium hirsutum L.) is one of the major crops in the Mid-South area. Both yield and quality of cotton are important factors in determining a producer's profit. Producing high-yielding and high-quality cotton requires careful management in every production stage, including proper application of water and nutrients. Water-stress in cotton plants can limit plant growth and productivity, resulting in reduction of yield (Cull, Hearn, \& Smith, 1981). Either under-use or over-use of $\mathrm{N}$ fertilizer can create negative effect on desired growth pattern of cotton plants and cause decrease of the yield and quality (Fernandez, McInnes, \& Cothren, 1996; Gerik, Oosterhuis, \& Torbert, 1998). Saleem, Bilal, Awais, Shahid, and Anjum (2010) tested three cotton cultivars with four $\mathrm{N}$ rates $(0,60,120$ and $180 \mathrm{~kg} \mathrm{ha}^{-1}$ ) and found that the $120 \mathrm{~kg} \mathrm{ha}^{-1}$ was the best $\mathrm{N}$ rate for high seed cotton yield and lint percentage. Girma, Teal, Freeman, Boman, and Ruan (2007) reported the $\mathrm{N}$ application rates greater than $90 \mathrm{~kg} \mathrm{ha}^{-1}$ degraded 
the lint quality. Pettigrew (2004) studied the effects of moisture deficit stress on cotton lint yield and fiber quality and reported that compared with irrigated plants, the dryland plants under water stress reduced lint yield by $25 \%$. Irrigated plants produced more bolls and approximately $2 \%$ longer fiber than the dryland plants. Balkcom, Revees, Shaw, Burmester, and Curtis (2006) investigated irrigation impact on cotton yield and quality with different tillage system. They observed that irrigation improved ginning percentage and increased yield, and the fiber quality parameters such as the length, micronaire, and uniformity were affected by the irrigation regimes. In a research by Basal Dagdelen, Unay, and Yilmaz (2009), it was showed that deficit irrigation of cotton with drip irrigation at $75 \%$ level did not decrease seed cotton yield and there was no significant differences in fiber length, fineness, uniformity, and elongation between the $100 \%$ and $75 \%$ irrigation levels. Whitaker, Ritchie, Bednarz, and Mills (2008) reported that non-irrigated cotton matured earlier than the irrigated. Irrigation methods, such as subsurface drip and overhead irrigation, had no significant effect on cotton fiber quality.

Cotton fiber produced in the United States is tested for quality by the United States Department of Agriculture (USDA) classing offices before entering the market. The principal instrumentation systems used for cotton fiber quality measurement are the High Volume Instrument (HVI) for commercial evaluation and the Advanced Fiber Information System (AFIS) (Uster Technologies, Knoxville, TN) often used by textile mills and researchers. Typical cotton fiber characteristics measured by these instruments are described by Peters and Meier (2010) and listed in the Appendix.

The objective of this research was to determine the effects of supplemental irrigation and nitrogen on cotton yield and cotton fiber quality.

\section{Materials and Methods}

\subsection{Experimental Setup and Conditions}

A field at a research farm of the USDA-ARS Crop Production Systems Research Unit in Stoneville, MS (latitude: $33^{\circ} 26^{\prime} 30.86^{\prime \prime}$, longitude: $\left.-90^{\circ} 53^{\prime} 26.60^{\prime \prime}\right)$ was used as an experimental site. Forty-eight plots were laid out in the experimental field in 2011 and 2012. Plots were $48.8 \mathrm{~m}$ by $23.2 \mathrm{~m}$ with a $7.7 \mathrm{~m}$-wide buffer between plots. Each plot contained 24 rows with row spacing of $0.97 \mathrm{~m}$. One soil sample from each plot was collected in the 2011 season before planting and analyzed for residual $\mathrm{N}$ and textural properties using the hydrometer method at Extension Service Soil Testing Laboratory of Mississippi State University. Soil texture of the field varied from silt to silt loam.

A split plot design was used in the study with 2 irrigation treatments (irrigated and non-irrigated) as the main unit, and $6 \mathrm{~N}$ treatments $\left(0,39,67,101,135\right.$, and $\left.168 \mathrm{~kg} \mathrm{ha}^{-1}\right)$ as the subunit. The main unit design was a randomized complete block (RCB) with 2 blocks. There were 2 replications (blocked) of the subunit within each main unit. This resulted in 12 plots in each block and 48 plots in total. One $\mathrm{N}$ application rate was randomly assigned to each plot in each block.

In 2011, cotton (cultivar 'DP 0912 B2RF') was planted on 8 May. Nitrogen in the designated rate was applied to each plot using a side knife drill on 24 June. Irrigation water was applied to alternate furrows using a poly-pipe system. The irrigated plots were irrigated twice during the 2011 season based on soil water content measured using soil moisture sensors (EC-5, Decagon Devices, Pullman, WA): $5 \mathrm{~cm}$ of water was applied on 6 July and $7.6 \mathrm{~cm}$ on 20 July. In the 2012 season, the same cotton cultivar was planted on 26 April, and the $\mathrm{N}$ fertilizer was applied on 8 June. Using the same irrigation scheduling method, total water depth of $16 \mathrm{~cm}(6.3$ ") was applied to the irrigated plots in five irrigation events during the season with a center pivot sprinkler irrigation system. Figures 1 and 2 respectively show soil moisture status and irrigation and precipitation events during the growing season in 2011 and 2012 respectively. From May to September, total precipitation was $35.1 \mathrm{~cm}$ in 2011 and $53.0 \mathrm{~cm}$ in 2012 (Figure 3). In 2011, non-irrigated plots were defoliated on September 8, and irrigated plots on 23 September. Cotton was machine harvested with a spindle-type picker on 11 October. In 2012, non-irrigated plots were defoliated on 21 August, and irrigated plots on 7 September. Second round defoliation was applied to non-irrigated plots on 6 September. Non-irrigated plots were picked on 27 September, and the irrigated on 17 October. In both seasons, several rains occurred between defoliation and harvest. 


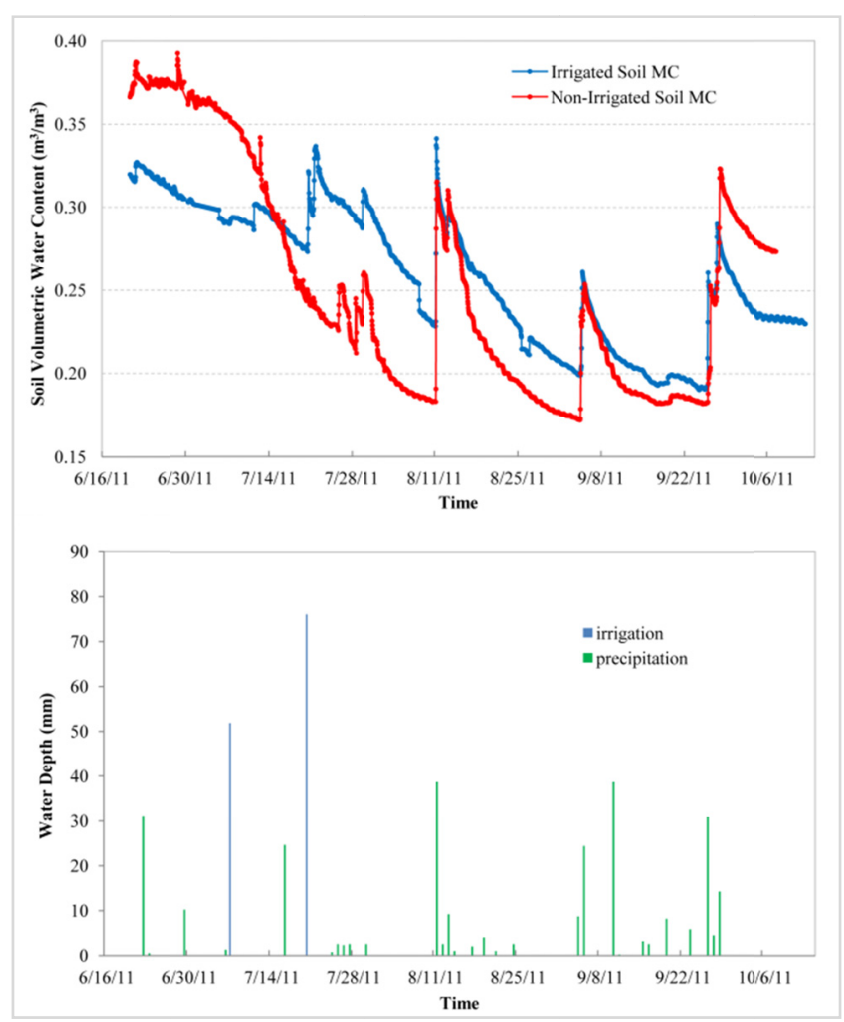

Figure 1. Soil moisture status, applied water and precipitation in 2011 season

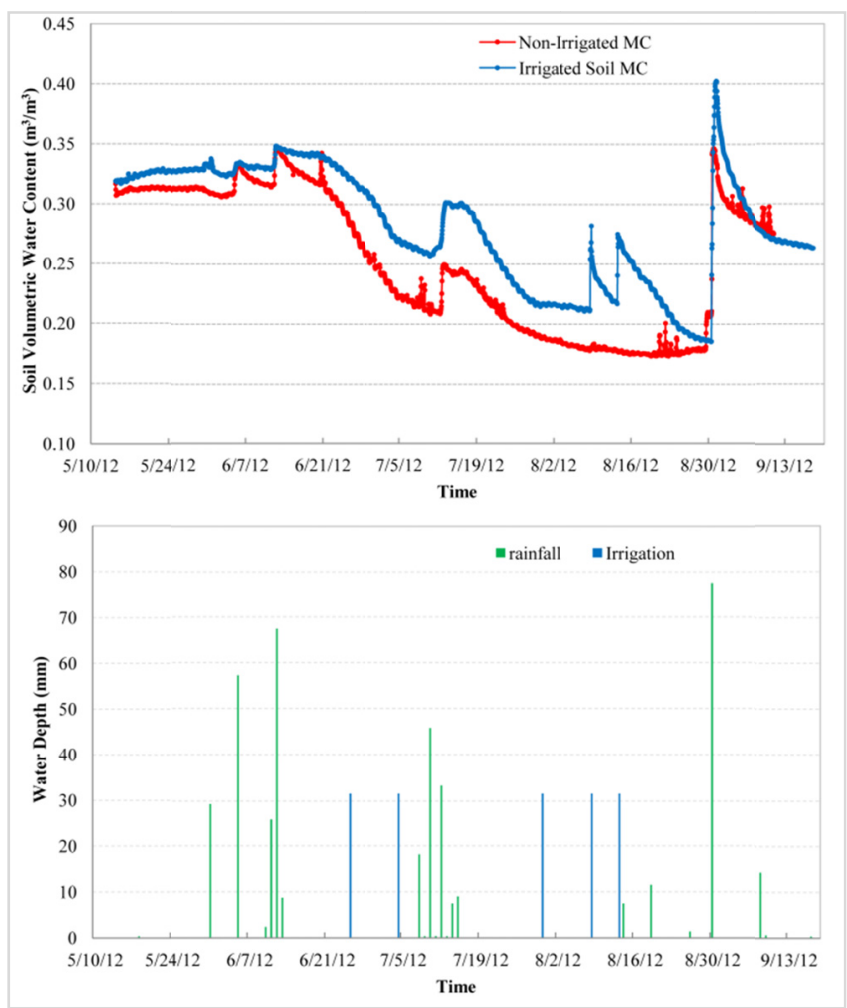

Figure 2. Soil moisture status, applied water and precipitation in 2012 season 


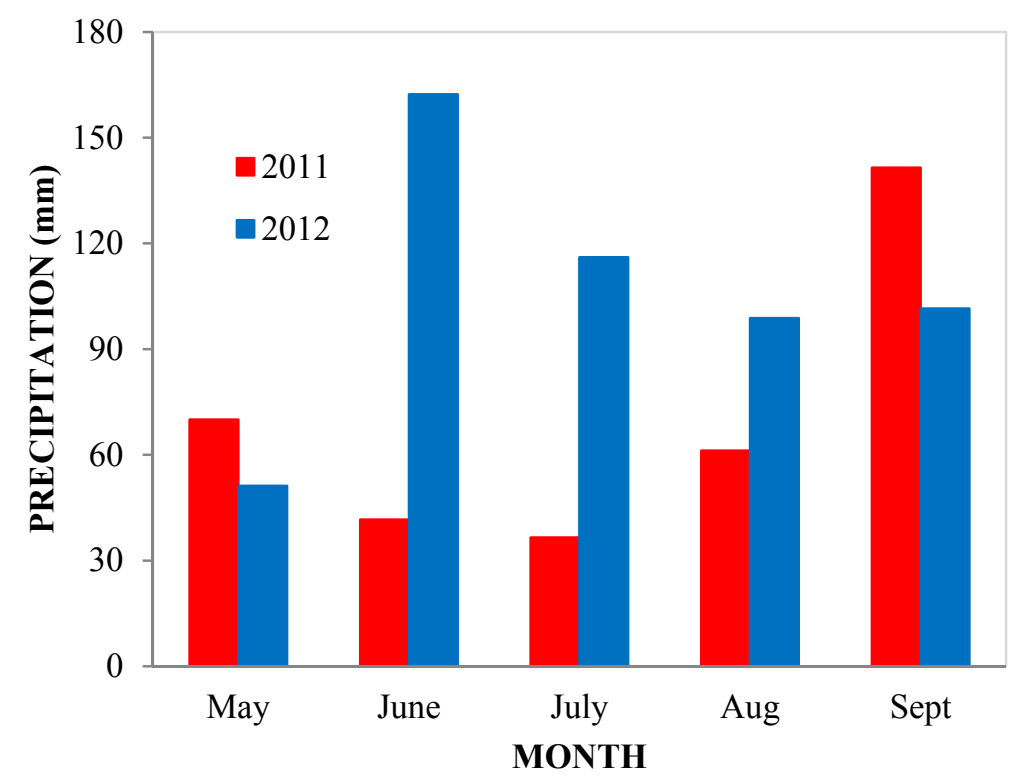

Figure 3. Precipitation distribution during cotton growing season in 2011 and 2012

\subsection{Sample Collection and Analysis}

Leaf samples were collected at 100 days after planting (DAP) in 2011. In 2012 leaf samples were collected in twice. The first round was $82 \mathrm{DAP}$ and the $2^{\text {nd }}$ was 103 DAP. Ten uppermost fully expanded main-stem leaves were taken to make one composite leaf sample. Three composite leaf samples were randomly collected in each plot, resulting in 144 leaf-blade samples in total. Leaf samples were analyzed by Kjeldahl procedure for $\mathrm{N}$ content. The average of $\mathrm{N}$ content values of the leaf samples from each plot was calculated to represent plant $\mathrm{N}$ status in the plot. Seed cotton harvested from the center rows of each plot was weighed for yield determination. Approximately $38 \mathrm{~kg}$ of seed cotton were randomly collected from each plot during harvesting for fiber quality analysis.

The seed cotton samples were ginned at the USDA-ARS Cotton Ginning Research Unit (CGRU) at Stoneville, MS. The ginning sequence included dryer 1, cylinder cleaner, dryer 2, stick machine, cylinder cleaner, extractor feeder gin stand, and saw-type lint cleaner. There was no heat added in the dryers in the ginning process. Thirteen sub-samples were collected after the lint cleaner from each sample, five of them for testing with Advanced Fiber Information System (AFIS), five for High Volume Instrument (HVI) and three for determining lint moisture content. Three sub-samples of seed cotton were taken before the gin stand for seed cotton moisture measurement. All lint samples were analyzed in the USDA-ARS SRRC (Southern Regional Research Center) in New Orleans, LA. Fiber quality parameters measured with AFIS and HVI tests included micronaire, fiber length, maturity, strength, elongation, color, and short fiber content. Since moisture of seed cotton may affect cotton lint properties in the ginning process, moisture content of the seed cotton and lint was determined by the conventional oven method at the USDA-ARS CGRU at Stoneville, MS (Shepherd, 1972).

\subsection{Data Analysis}

An ANOVA was performed with SAS software using the PROC MIXED procedure (SAS Institute Inc., Cary, NC) to evaluate the effect of irrigation and leaf $\mathrm{N}$ on yield and fiber quality. In this analysis, irrigation treatment was a fixed effect; the block within irrigation treatment was a random effect and degrees of freedom calculations were based on Kenward/Roger option (Littell, Milliken, Stroup, Wolfinger, \& Schabenberger, 2006).

\section{Results and Discussion}

\subsection{Cotton Yield}

In 2011, seed cotton yield of irrigated plots ranged from $2851 \mathrm{~kg} \mathrm{ha}^{-1}$ to $4417 \mathrm{~kg} \mathrm{ha}^{-1}$ with a mean of $3399 \mathrm{~kg} \mathrm{ha}^{-1}$ $\left(\mathrm{SD}=391 \mathrm{~kg} \mathrm{ha}^{-1}\right)$. The mean seed cotton yield in non-irrigated plots was $2975 \mathrm{~kg} \mathrm{ha}^{-1}\left(\mathrm{SD}=309 \mathrm{~kg} \mathrm{~h}^{-1}\right)$ with a minimum of $2208 \mathrm{~kg} \mathrm{ha}^{-1}$ and a maximum of $3421 \mathrm{~kg} \mathrm{ha}^{-1}$. The ANOVA indicated that yield of irrigated plots was significantly higher than the yield of the non-irrigated $(\mathrm{F}=17.02, \mathrm{p}=0.0002)$. Overall, supplemental irrigation increased seed cotton yield by $14.2 \%$ in the 2011 season. In the 2012 season, irrigation increased the yield by $13.4 \%$ with an average seed cotton yield of $1921 \mathrm{~kg} \mathrm{ha}^{-1}\left(\mathrm{SD}=669 \mathrm{~kg} \mathrm{ha}^{-1}\right)$ in non-irrigated plots and $2179 \mathrm{~kg} \mathrm{ha}^{-1}$ 
$\left(\mathrm{SD}=400 \mathrm{~kg} \mathrm{ha}^{-1}\right)$ in the irrigated plots. In terms of percentage, yield increase attributed by irrigation was similar in both years. However, the effect of irrigation on yield was statistically significant in 2011, but not in 2012 .

Plant leaf $\mathrm{N}$ content in 2011 was in the range of $3.73 \%$ to $5.86 \%$ with an average of $4.94 \%(\mathrm{SD}=0.50 \%)$ in irrigated plots and $4.53 \%(\mathrm{SD}=0.25 \%)$ in non-irrigated plots. The leaf $\mathrm{N}$ content in irrigated plots was $9.0 \%$ higher than that in non-irrigated plots. In 2012, plant leaf $\mathrm{N}$ ranged from $3.27 \%$ to $4.46 \%$. Average leaf $\mathrm{N}$ content was $4.03 \%$ in irrigated plots $(\mathrm{SD}=0.32 \%)$ and $3.89 \%$ in the non-irrigated $(\mathrm{SD}=0.24 \%$ ), which was $3.60 \%$ lower than that in the irrigated plots. For both years, irrigated cotton crops had higher leaf $\mathrm{N}$ content than the non-irrigated, and the variation of leaf $\mathrm{N}$ content in irrigated plots was greater than that in non-irrigated. A critical value of cotton leaf $\mathrm{N}$ at early bloom in the Mid-South U.S. was about 4\% and cotton plants might be considered to be under $\mathrm{N}$ stress if leaf $\mathrm{N}$ concentrations are less than this value (Bell et al., 1998). Due to the large amount of residual $\mathrm{N}$ in the soil, there was one plot in 2011 and 22 plots in 2012 in which the plant leaf $\mathrm{N}$ was slightly lower than the critical value. The ANOVA result showed that the effect of leaf $\mathrm{N}$ on yield was not significant in $2011(\mathrm{~F}=0.08, \mathrm{p}=0.7774)$ and in $2012(\mathrm{~F}=1.19, \mathrm{p}=0.2819)$. However, linear relationships between yield and leaf $\mathrm{N}$ content existed for both the irrigated plots $\left(r^{2}=0.46\right)$ and the non-irrigated plots $\left(r^{2}=0.36\right)$ (Figure 4$)$.

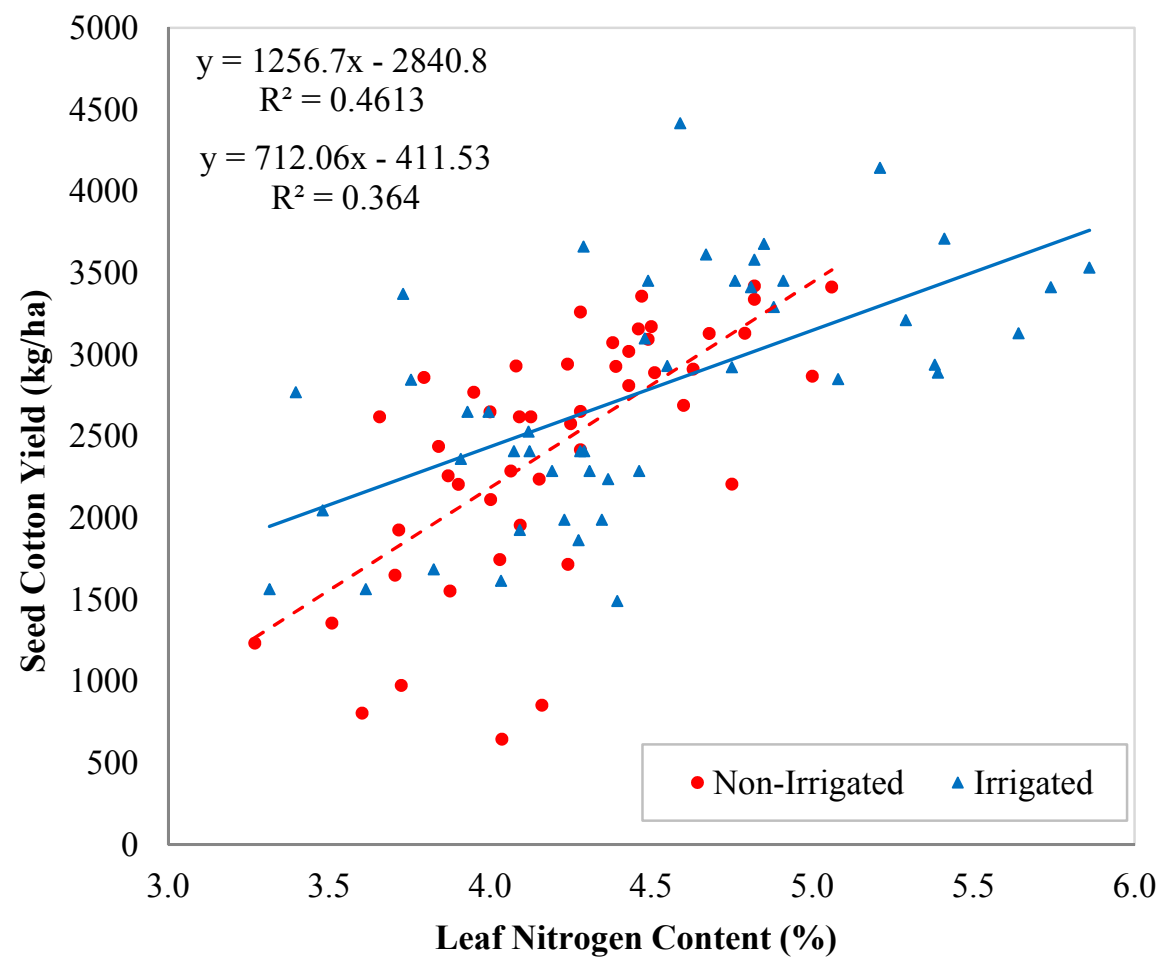

Figure 4. Relationships between plant leaf nitrogen content and yield for irrigated and non-irrigated plots

\subsection{Cotton Fiber Quality}

A summary of sample moisture data is given in Table 1 . In the 2011 season, seed cotton moisture content before the gin stand was $7.64 \%$ for irrigated cotton and $7.61 \%$ for the non-irrigated. Lint moisture after the lint cleaner was $4.44 \%$ for the irrigated and $4.46 \%$ for the non-irrigated. The ANOVA analysis revealed that the moisture content of irrigated cotton samples did not significantly differ from that of non-irrigated samples before the gin stand $(\mathrm{F}=0.02, \mathrm{p}=0.8835)$ and after the lint cleaner $(\mathrm{F}=0.03, \mathrm{p}=0.8693)$. In 2012, seed cotton moisture content was $8.45 \%$ for the irrigated cotton and $7.82 \%$ for non-irrigated cotton. The moisture difference between irrigated and non-irrigated samples was significant. However, moisture content of all samples was in a range in which cotton fiber quality should not be significantly affected during the ginning process (Anthony \& Mayfield, 1994). 
Table 1. Moisture content of samples collected before the gin stand and after the lint cleaner. Means with the same letter are not significantly different at the 0.05 level

\begin{tabular}{ccccccc}
\hline Season & Type & Treatment & Mean (\%) & Max (\%) & Min (\%) & STDEV \\
\hline \multirow{4}{*}{$\mathbf{2 0 1 1}$} & \multirow{2}{*}{ Seed Cotton } & Irrigated & $7.64^{\mathrm{a}}$ & 9.38 & 6.35 & 0.72 \\
& & Non-irrigated & $7.61^{\mathrm{a}}$ & 8.87 & 5.69 & 0.86 \\
& \multirow{3}{*}{ Lint } & Irrigated & $4.44^{\mathrm{b}}$ & 4.82 & 3.93 & 0.28 \\
& \multirow{4}{*}{$\mathbf{2 0 1 2}$} & Non-irrigated & $4.46^{\mathrm{b}}$ & 5.18 & 3.78 & 0.31 \\
& \multirow{2}{*}{ Seed Cotton } & Irrigated & $8.45^{\mathrm{c}}$ & 9.35 & 7.68 & 0.42 \\
& \multirow{3}{*}{ Lint } & Non-irrigated & $7.82^{\mathrm{d}}$ & 9.21 & 6.77 & 0.58 \\
& & Irrigated & $5.23^{\mathrm{e}}$ & 5.90 & 4.52 & 0.41 \\
& & Non-irrigated & $4.80^{\mathrm{f}}$ & 5.23 & 4.48 & 0.24 \\
\hline
\end{tabular}

Table 2 shows the results of the ANOVA test on AFIS fiber property measurements. In the 2011 season, fiber length, upper quartile length (UQL), nep, dust, fineness, and maturity differed significantly as a function of irrigation treatment at the 0.05 level while the short fiber content (SFC) did not. Fiber length and UQL of irrigated cotton were $2.1 \%$ and $2.4 \%$ greater than that of the non-irrigated cotton, respectively. This results were consistent with that reported by Pettigrew (2004). Short fiber content was about the same for irrigated and non-irrigated cotton. Effects of leaf $\mathrm{N}$ on the length, UQL, and SFC were not significant. The ANOVA test also showed that effects of leaf $\mathrm{N}$ on nep, fineness, and maturity were significant while the effects on the other AFIS properties were not significant. Interaction of irrigation with plant leaf $\mathrm{N}$ was not significant for fiber length, SFC, and UQL. However, the interaction was significant with nep, dust, fineness, and maturity. This demonstrated that the effect of leaf $\mathrm{N}$ on those fiber properties depended on whether the plots were irrigated. Means of nep, dust, fineness, and maturity given in Table 2 were calculated with the mean of leaf $\mathrm{N}$, which was $4.73 \%$. It was observed that the irrigated cotton had less dust than the non-irrigated while it had more neps than the non-irrigated. However, these were not the case for 2012 season.

Table 2. Results of the ANOVA test to compare effects of irrigation and leaf $\mathrm{N}$ on AFIS fiber properties in 2011 and 2012

\begin{tabular}{|c|c|c|c|c|c|c|c|c|c|}
\hline \multirow{2}{*}{$\begin{array}{c}\text { Fiber } \\
\text { property }\end{array}$} & \multirow[b]{2}{*}{ Season } & \multicolumn{4}{|c|}{ Irrigation } & \multicolumn{2}{|c|}{ Leaf $N$} & \multicolumn{2}{|c|}{ Irrigation*Leaf $\mathrm{N}$} \\
\hline & & $\begin{array}{c}\text { Irr } \\
\text { Mean }^{z}\end{array}$ & $\begin{array}{l}\text { Non-irr } \\
\text { Mean }^{y}\end{array}$ & F Value & $\mathbf{p r}>\mathbf{F}$ & F Value & $\mathrm{pr}>\mathrm{F}$ & F Value & $\mathbf{p r}>\mathbf{F}$ \\
\hline \multirow{2}{*}{$\mathbf{L}(\mathrm{w})(\mathbf{m m})$} & 2011 & 24.89 & 24.38 & 23.06 & $<0.0001$ & 0.90 & 0.3471 & 0.27 & 0.6091 \\
\hline & 2012 & 24.89 & 24.64 & 2.33 & 0.2664 & 0.54 & 0.4672 & 0.58 & 0.4523 \\
\hline \multirow{2}{*}{ SFC(w) (\%) } & 2011 & 7.64 & 7.52 & 0.34 & 0.6169 & 1.40 & 0.2431 & 1.97 & 0.1675 \\
\hline & 2012 & 8.07 & 8.26 & 0.27 & 0.6566 & 4.35 & 0.0426 & 0.11 & 0.7438 \\
\hline \multirow{2}{*}{ UQL(w) (mm) } & 2011 & 29.72 & 28.96 & 44.96 & $<0.0001$ & 0.43 & 0.5167 & 0.91 & 0.3466 \\
\hline & 2012 & 29.97 & 29.46 & 50.39 & $<0.0001$ & 0.37 & 0.5445 & 0 & 0.9534 \\
\hline \multirow{2}{*}{ Nep (cnt/g) } & 2011 & 228.66 & 204.60 & 7.62 & 0.0088 & 4.62 & 0.0378 & 6.44 & 0.0152 \\
\hline & 2012 & 177.42 & 181.85 & 0.10 & 0.7777 & 1.30 & 0.2594 & 0.16 & 0.695 \\
\hline \multirow{2}{*}{ Dust (cnt/g) } & 2011 & 280.23 & 350.91 & 4.24 & 0.0462 & 3.82 & 0.0577 & 4.93 & 0.032 \\
\hline & 2012 & 283.78 & 275.37 & 0.01 & 0.9482 & 9.95 & 0.0029 & 1.20 & 0.2794 \\
\hline \multirow{2}{*}{ Fine (mtex) } & 2011 & 177.69 & 172.94 & 7.46 & 0.0091 & 6.64 & 0.0135 & 8.04 & 0.0069 \\
\hline & 2012 & 173.66 & 173.79 & 0 & 0.9839 & 2.17 & 0.1478 & 0.45 & 0.5051 \\
\hline \multirow{2}{*}{ MatRat } & 2011 & 0.95 & 0.94 & 8.22 & 0.0069 & 5.79 & 0.0212 & 8.18 & 0.0069 \\
\hline & 2012 & 0.93 & 0.94 & 0.09 & 0.7941 & 2.82 & 0.0998 & 1.25 & 0.2694 \\
\hline
\end{tabular}

${ }^{\mathrm{z}}$ Mean value in irrigated plots; ${ }^{\mathrm{y}}$ Mean value in non-irrigated plots. 
In 2012, effect of irrigation on UQL was significant $(F=50.39, p<0.0001)$, but was not significant on the other AFIS properties. The UQL of irrigated cotton fiber was $1.7 \%$ longer than that of the non-irrigated. Fiber length and short fiber content were slightly improved by irrigation. Fineness in irrigated cotton was about the same as in the non-irrigated. The ANOVA revealed that leaf $\mathrm{N}$ had a significant effect on short fiber content $(\mathrm{F}=4.35, \mathrm{p}=0.0426)$ and dust content $(\mathrm{F}=9.95, \mathrm{p}=0.0029)$.

Combining the data of years 2011 and 2012, the UQL, fiber length, and nep content versus leaf $\mathrm{N}$ content are shown in Figures 5, 6, and 7, respectively. It was indicated that irrigation improved fiber UQL and fiber length though the degree of the improvement might not make a difference on market price of cotton. A trend was illustrated that fiber length decreased and neps increased with increasing leaf $\mathrm{N}$ content.

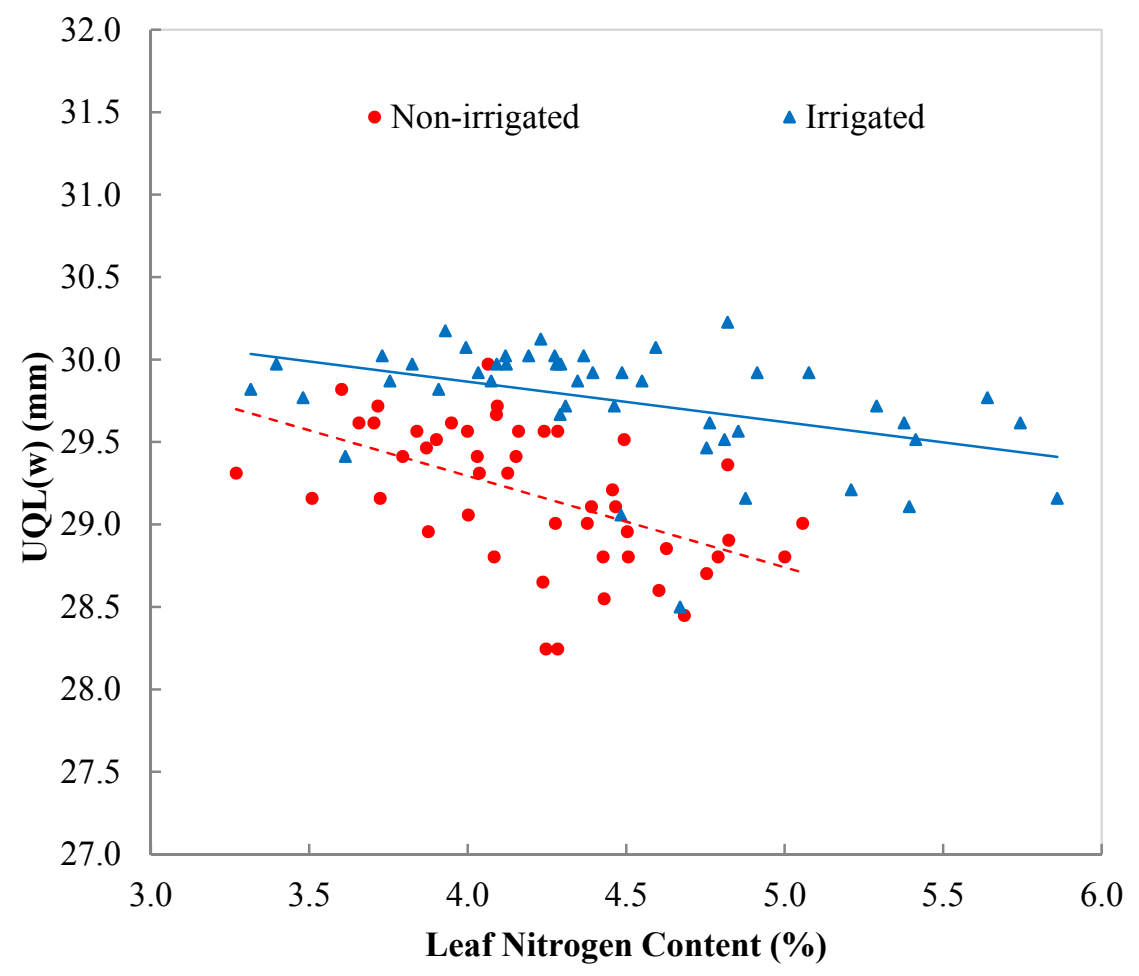

Figure 5. UQL of irrigated and non-irrigated cotton versus leaf nitrogen content 


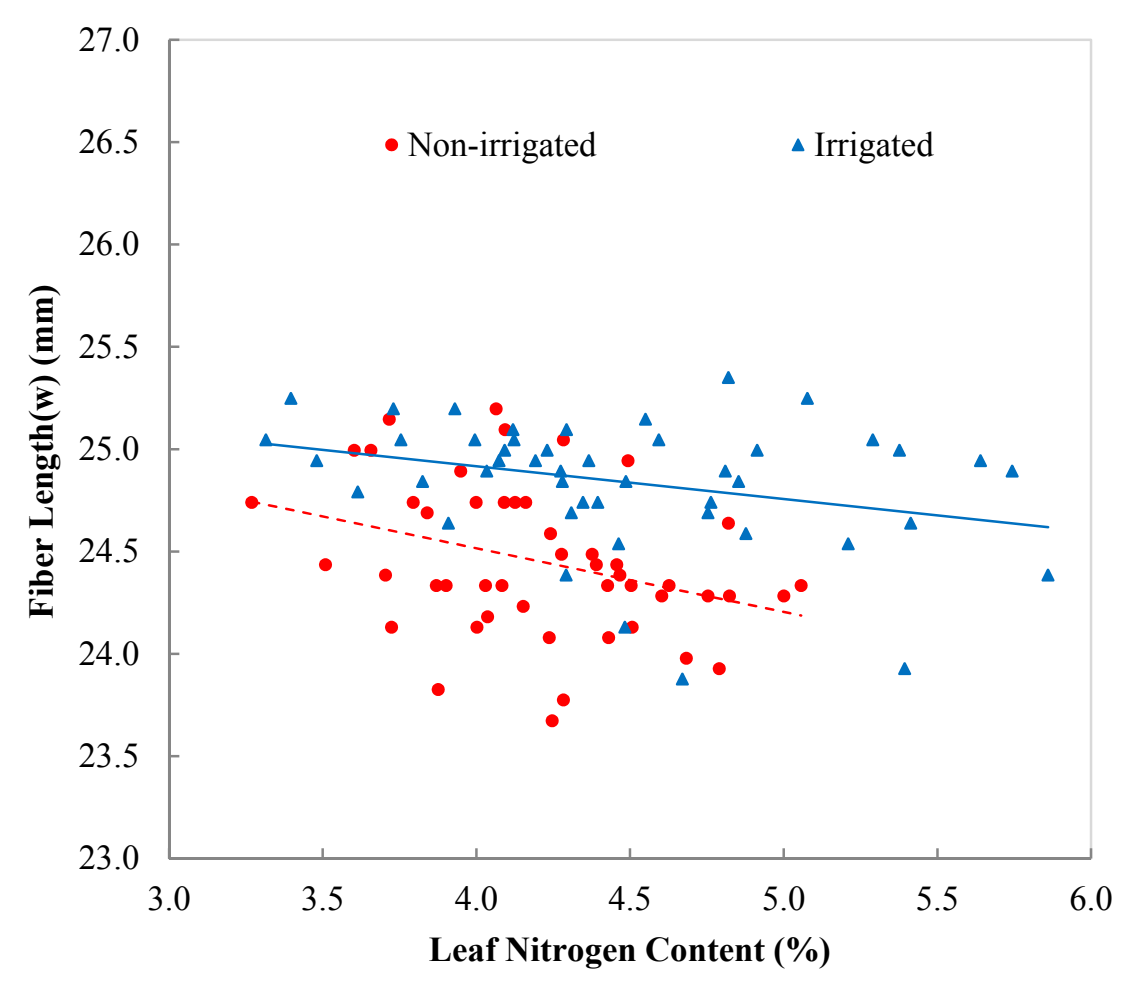

Figure 6. Fiber length versus leaf $\mathrm{N}$ content in irrigated and non-irrigated plots

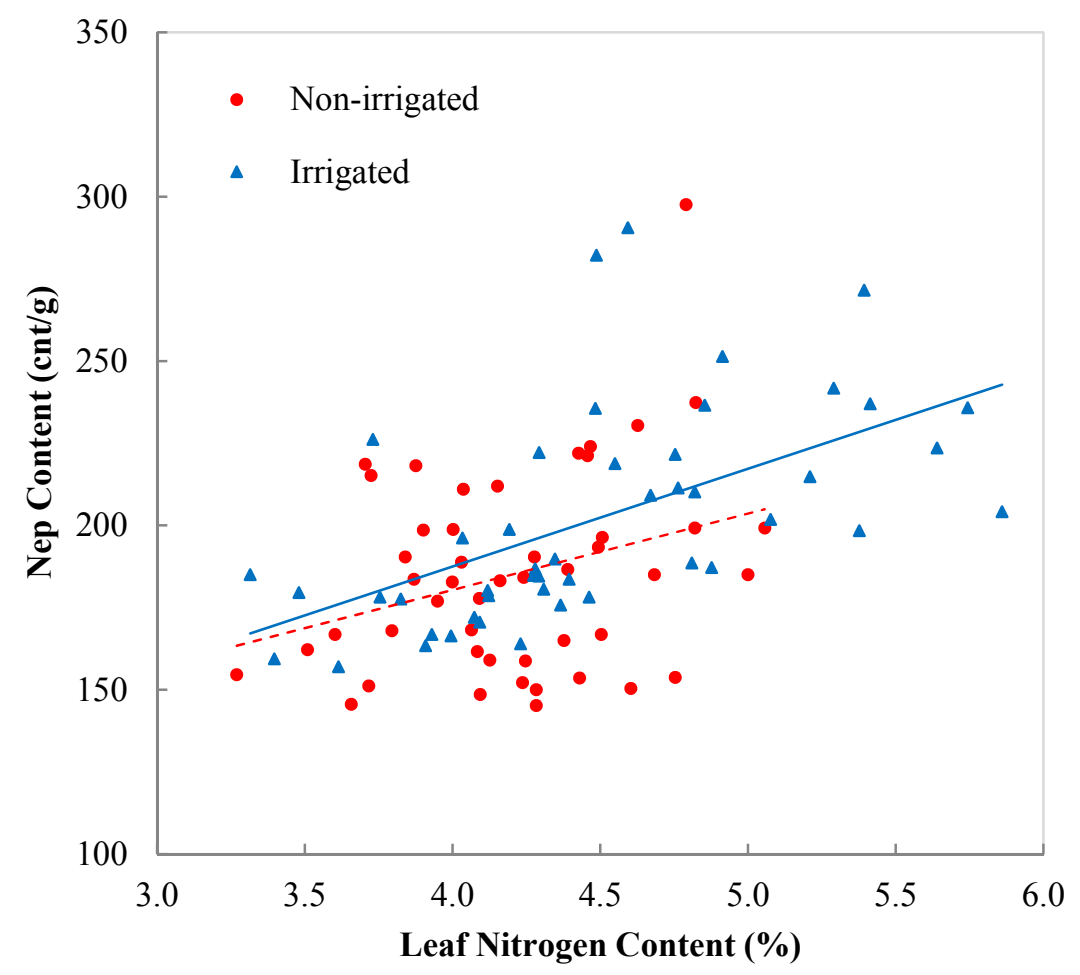

Figure 7. Nep content versus leaf nitrogen content

The effects of irrigation and N on HVI fiber properties are shown in Table 3. In the 2011 season, the ANOVA test revealed that the effects of irrigation on micronaire, UHML, short fiber content, Rd, and TrAr were significant. 
UHML of irrigated cotton $(M=28.45)$ was $2.7 \%$ greater than that of non-irrigated cotton $(M=27.69)$, and the difference was statistically significant. Short fiber content of the irrigated cotton $(M=8.94 \%)$ was lower than that of the non-irrigated $(M=9.26 \%)$. The irrigated cotton had a higher reflectance value $(M=79.45)$ than the non-irrigated $(\mathrm{M}=75.44)$. The ANOVA results also indicated that the effects of irrigation on UI, strength, elongation, and yellowness were not significant. Micronaire, yellowness $(+b)$, and $\operatorname{TrAr}$ differed significantly as a function of leaf nitrogen. Interaction of irrigation and leaf $\mathrm{N}$ was significant in micronaire and TrAr. Effects of leaf $\mathrm{N}$ on micronaire and $\mathrm{Tr} A \mathrm{r}$ depended on irrigation.

Table 3. Results of the ANOVA test to determine effects of irrigation and leaf $\mathrm{N}$ on HVI fiber properties in 2011 and 2012

\begin{tabular}{|c|c|c|c|c|c|c|c|c|c|}
\hline \multirow{2}{*}{ Fiber Property } & \multirow{2}{*}{ Season } & \multicolumn{4}{|c|}{ Irrigation } & \multicolumn{2}{|c|}{ Leaf $N$} & \multicolumn{2}{|c|}{ Irrigation*Leaf $\mathrm{N}$} \\
\hline & & Irr Mean & Non-irr Mean & F Value & pr $>$ F & F Value & pr $>$ F & F Value & $\mathbf{p r}>\mathbf{F}$ \\
\hline \multirow{2}{*}{ Mic } & 2011 & 4.37 & 4.32 & 5.48 & 0.0244 & 6.06 & 0.0183 & 5.38 & 0.0255 \\
\hline & 2012 & 4.81 & 4.60 & 1.82 & 0.3095 & 1.37 & 0.2477 & 0.33 & 0.5708 \\
\hline \multirow{2}{*}{ UHML (mm) } & 2011 & 28.45 & 27.69 & 17.00 & 0.0541 & 0.21 & 0.6521 & 1.14 & 0.2911 \\
\hline & 2012 & 28.19 & 27.69 & 22.83 & 0.0411 & 0.14 & 0.7107 & 0.86 & 0.3585 \\
\hline UI & 2011 & 82.27 & 81.63 & 13.22 & 0.068 & 0.03 & 0.8555 & 0.34 & 0.561 \\
\hline$(\%)$ & 2012 & 81.47 & 81.38 & 0.07 & 0.8174 & 0.08 & 0.7818 & 0.28 & 0.5987 \\
\hline SFI & 2011 & 8.94 & 9.26 & 27.48 & 0.0345 & 0.18 & 0.6763 & 0.11 & 0.7444 \\
\hline$(\%)$ & 2012 & 8.70 & 9.57 & 1.73 & 0.3186 & 0.02 & 0.8959 & 0.53 & 0.4693 \\
\hline Str & 2011 & 30.53 & 31.05 & 2.14 & 0.2809 & 0.52 & 0.4769 & 0.23 & 0.633 \\
\hline$(g / t e x)$ & 2012 & 29.61 & 29.12 & 0.82 & 0.4606 & 0.06 & 0.8041 & 1.69 & 0.2000 \\
\hline Elg & 2011 & 6.25 & 5.93 & 4.46 & 0.1692 & 1.33 & 0.2556 & 0.11 & 0.7403 \\
\hline (\%) & 2012 & 6.40 & 6.41 & 0.03 & 0.8717 & 0 & 0.9547 & 0.29 & 0.5952 \\
\hline \multirow{2}{*}{ Rd } & 2011 & 79.45 & 75.44 & 67.19 & 0.0146 & 0.68 & 0.4133 & 1.98 & 0.1669 \\
\hline & 2012 & 74.78 & 76.05 & 1.86 & 0.3061 & 0.07 & 0.7965 & 0.01 & 0.9342 \\
\hline \multirow{2}{*}{$+\mathbf{b}$} & 2011 & 7.69 & 7.50 & 1.35 & 0.3596 & 5.19 & 0.0278 & 0.45 & 0.5086 \\
\hline & 2012 & 7.03 & 7.17 & 5.54 & 0.0232 & 10.47 & 0.0023 & 4.92 & 0.0317 \\
\hline TrAr & 2011 & 0.35 & 0.49 & 5.39 & 0.0251 & 7.65 & 0.0083 & 7.01 & 0.0113 \\
\hline$(\%)$ & 2012 & 0.29 & 0.29 & 0.02 & 0.8974 & 1.96 & 0.1688 & 0.85 & 0.3621 \\
\hline
\end{tabular}

The ANOVA test on the 2012 HVI data indicated the effects of irrigation on UHML and yellowness were significant, but not significant for other HVI properties. The UHML of irrigated cotton was $1.8 \%$ greater than the non-irrigated and the difference was significant $(\mathrm{F}=22.83, \mathrm{p}=0.0411)$. Although the effect of irrigation on short fiber index was not significant, the short fiber index of irrigated cotton was less than that of the non-irrigated. Unlike in 2011, effects of leaf $\mathrm{N}$ on micronaire and TrAr were not significant in 2012. However, the effect of leaf $\mathrm{N}$ on the yellowness remained significant in 2012 .

Pooling the data obtained in 2011 and 2012, cotton fiber properties including UHML, short fiber index, micronaire, and yellowness are plotted against leaf $\mathrm{N}$ content in Figures 8 through 11, respectively. It was observed that irrigation improved cotton fiber length (Figure 8). Irrigated cotton had less short fiber than the non-irrigated (Figure 9). Micronaire of irrigated cotton was slightly higher than the non-irrigated cotton, and there was a linear trend with micronaire decreasing with increasing leaf $\mathrm{N}\left(\mathrm{r}^{2}=0.25\right)$ (Figure 10). Micronaire is affected by maturity. The irrigated plants had a longer growing season than the non-irrigated, which might influence the maturity. Plants with higher leaf $\mathrm{N}$ could have more upper bolls and bolls in the third and fourth sympodial positions that would be lower in the micronaire. Within the variation range of leaf $\mathrm{N}$ content in this study, UHML and short fiber index showed very weak correlations with leaf $\mathrm{N}$ content. Fiber yellowness had a fairly strong positive correlation with leaf $\mathrm{N}$ content $\left(\mathrm{r}^{2}=0.43\right)$ (Figure 11). Reflectance of fibers was also positively correlated with leaf $\mathrm{N}\left(\mathrm{r}^{2}=0.21\right)$. In average, the color grade of the samples was $41-1$ with leaf $\mathrm{N}$ range from $3.27 \%$ to $4.91 \%$, 
and $31-1$ with leaf $\mathrm{N}$ of $5.00 \%$ to $5.86 \%$. Higher leaf $\mathrm{N}$ slightly improved the color grade. However, this effect would not be significant on market value of the cotton. This signified that over-application of $\mathrm{N}$ would not benefit fiber HVI properties such as UHML and short fiber index while causing increase of farming costs.

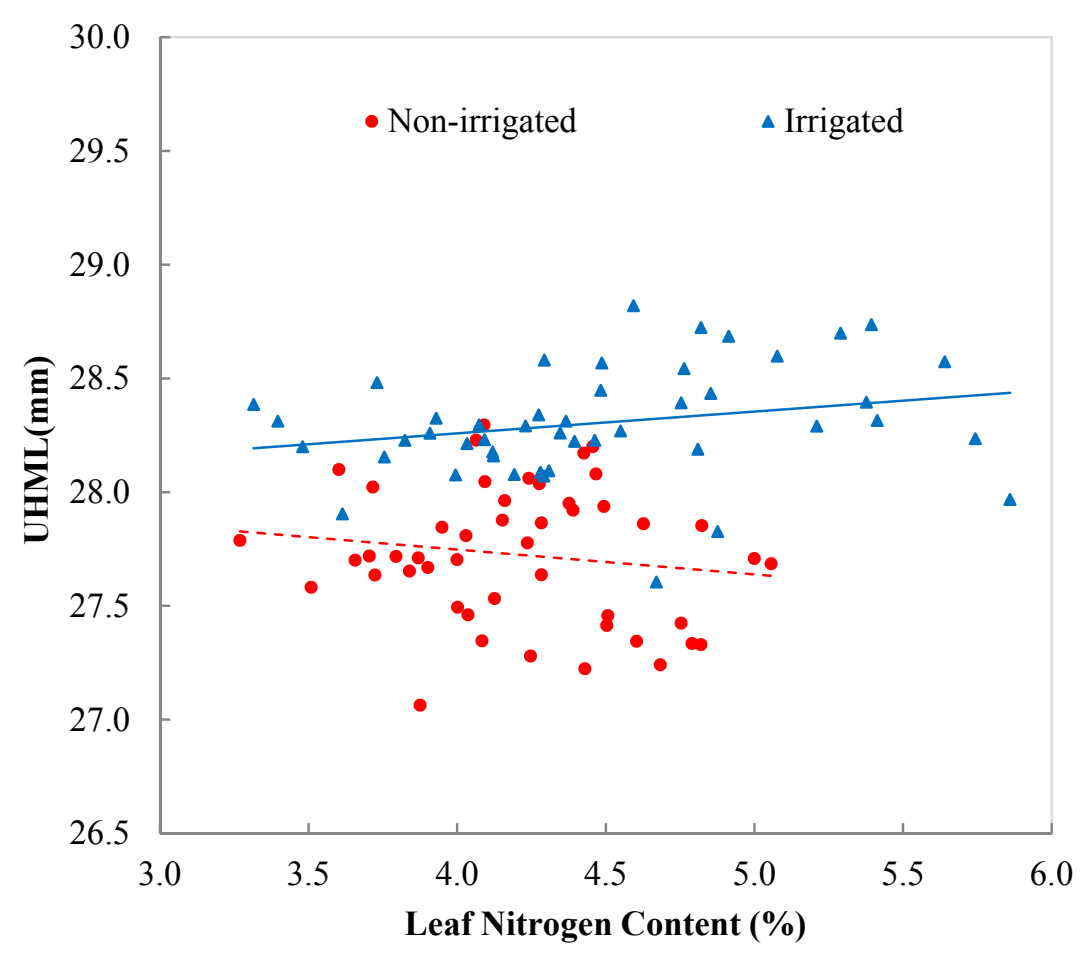

Figure 8. UHML difference between irrigated and non-irrigated plots

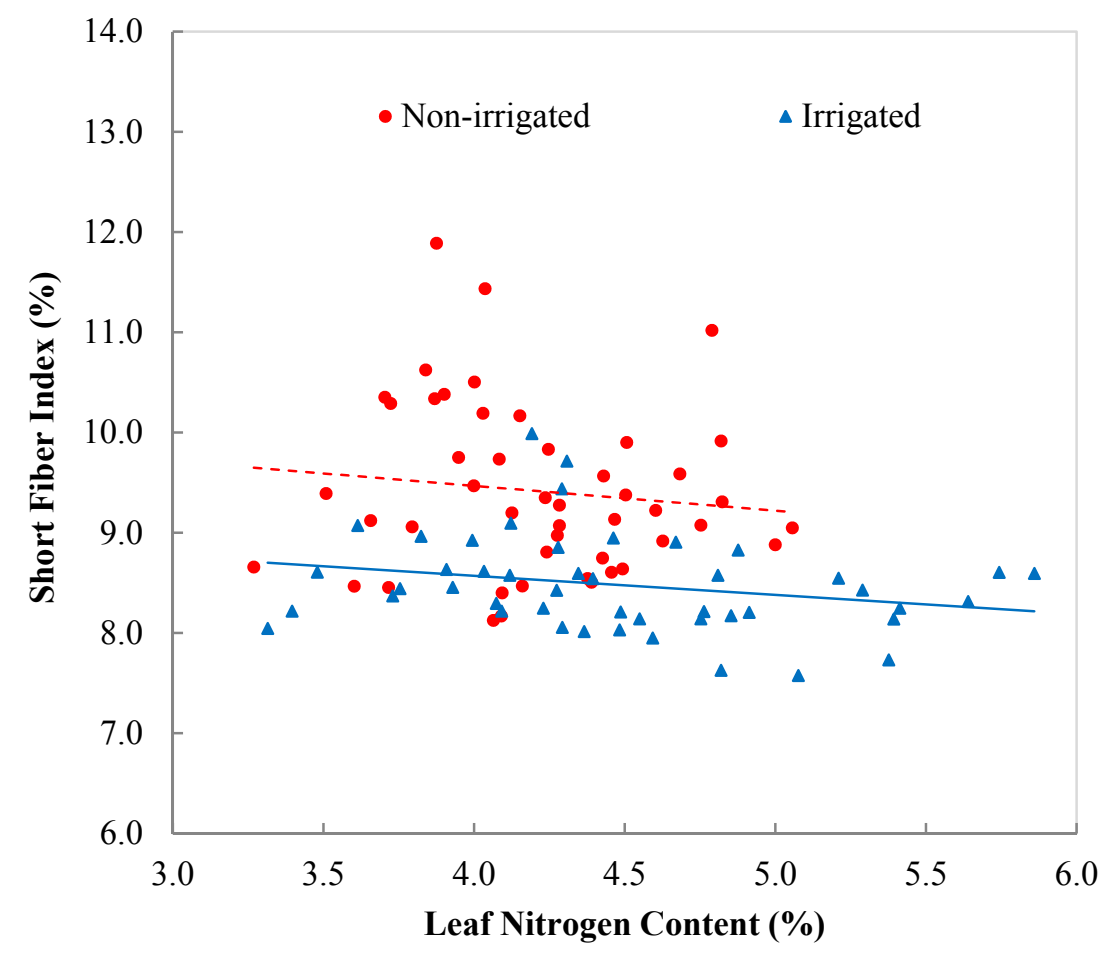

Figure 9. Irrigated cotton had less short fibers than the non-irrigated cotton 


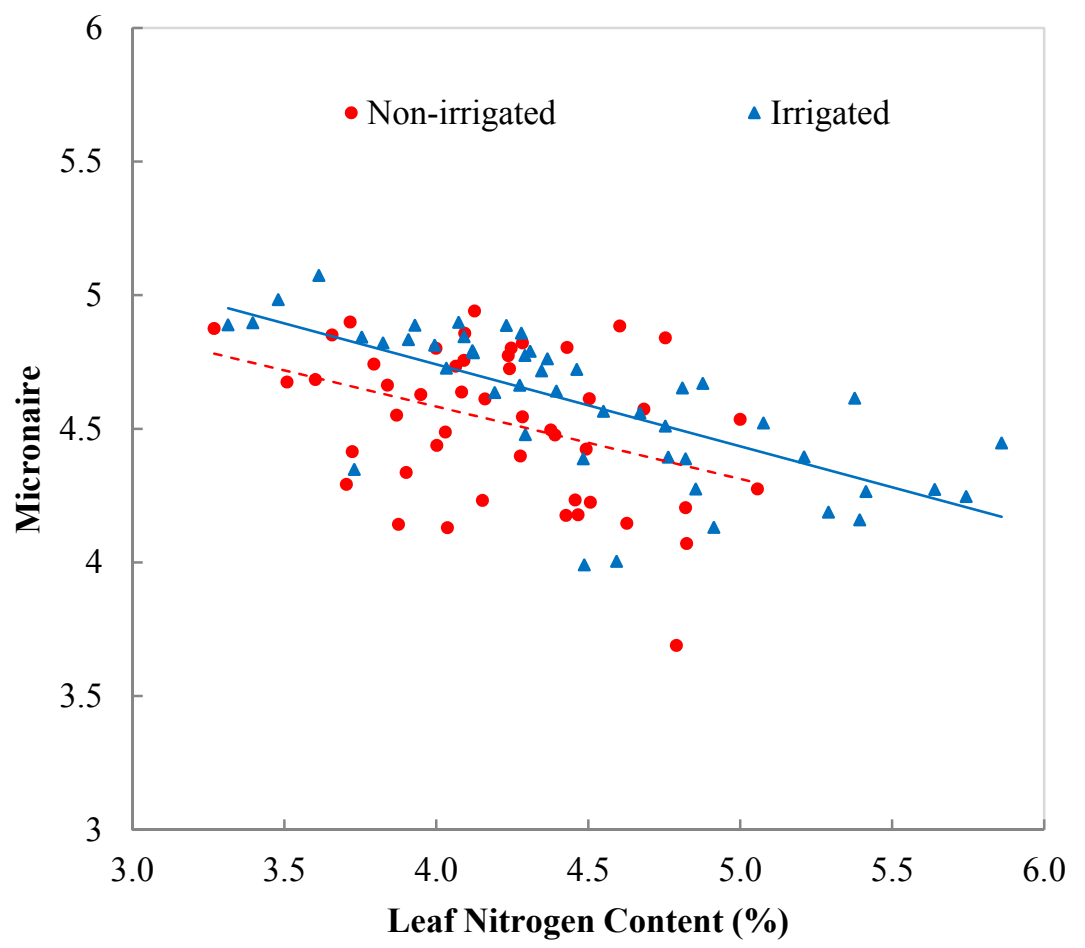

Figure 10. Micronaire of irrigated and non-irrigated cotton versus leaf nitrogen content

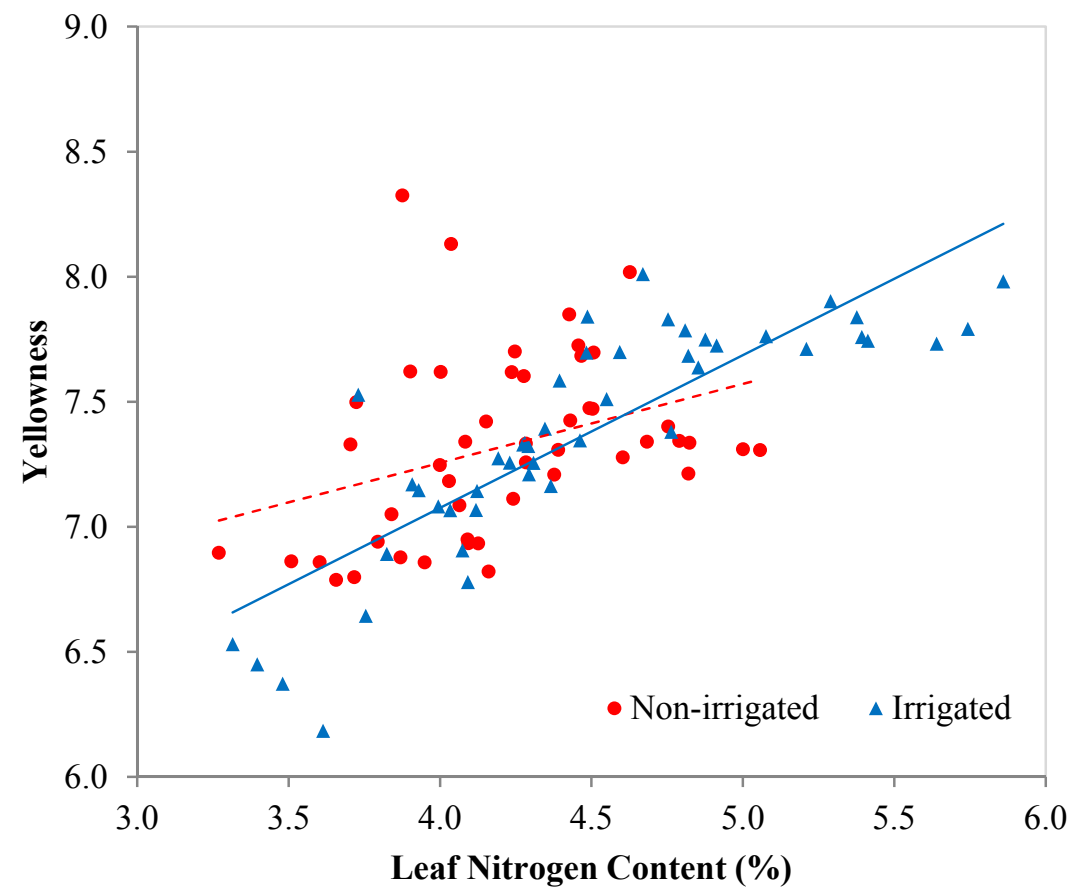

Figure 11. Cotton fiber yellowness increased with the increase of leaf $\mathrm{N}$ content

\section{Conclusions}

Experiments were conducted for two years in Stoneville, MS to investigate the effects of supplemental irrigation and $\mathrm{N}$ fertilization on yield and fiber quality in cotton. It was found that supplemental irrigation increased seed cotton yield by $14 \%$. Leaf $\mathrm{N}$ of irrigated plants was $9.0 \%$ and $3.6 \%$ higher than that of the non-irrigated plants in 
2011 and 2012, respectively. Soil water stress had a negative effect on N uptake of cotton plants. Cotton fiber length as measured by UQL, UHML, and UI showed improvements with irrigation. UHML in irrigated treatment was $2.7 \%$ and $1.8 \%$ greater than the non-irrigated treatment in 2011 and 2012, respectively. Irrigated cotton had lower short fiber index than the non-irrigated. Micronaire of irrigated cotton was slightly higher than that of the non-irrigated. The effects of irrigation on other fiber properties were not consistent in these two years. Micronaire decreased as the leaf $\mathrm{N}$ content increased. Neps and fiber yellowness increased with the increase of leaf $\mathrm{N}$ content. As the leaf $\mathrm{N}$ content reached a sufficient level, over-application of $\mathrm{N}$ would not be beneficial to cotton fiber quality while possibly degrading some fiber properties.

\section{Acknowledgements}

Authors extend their appreciation to Deborah Boykin of USDA ARS Mid South Area at Stoneville, Mississippi for her assistance in statistics analysis. This study was partially supported by Cotton Incorporated.

\section{Disclaimer}

Mention of a commercial product is solely for the purpose of providing specific information and should not be construed as a product endorsement by the authors or the institutions with which the authors are affiliated.

\section{References}

Anthony, W. S., \& Mayfield, W. D. (Eds). (1994). Cotton Ginners Handbook. rev. U.S. Department of Agriculture, Agricultural Handbook 503.

Balkcom, K. S., Reeves, D. W., Shaw, J. N., Burmester, C. H., \& Curtis, L. M. (2006). Cotton yield and fiber quality from irrigated tillage system in the Tennessee Valley. Agron. J., 98(3), 596-602. http://dx.doi.org/10.2134/agronj2005.0219

Bakhsh, A., Kanwar, R. S., Bailey, T. B., Cambardella, C. A., Karlen, D. L., \& Colvin, T. S. (2002). Cropping system effects on $\mathrm{NO}_{3}-\mathrm{N}$ loss with subsurface drainage water. Trans. ASAE, 45(6), 1789-1797. http://dx.doi.org/10.13031/2013.11430

Basal, H., Dagdelen, A., Unay, A., \& Yilmaz, E. (2009). Effects of deficit drip irrigation rations on cotton (Gossypium hirsutum L.) yield and fiber quality. J. Agronomy \& Crop Science, 195, 19-29. http://dx.doi.org/10.1111/j.1439-037X.2008.00340.x

Bell, P. F., Breitenbeck, G., Funderburg, E., Boquet, D., Millhollon, E., Holman, M., ... Robinson, W. (1998). A four-state study to develop a leaf-blade nitrogen test for cotton in the Midsouth. In Proceedings of the Beltwide Cotton Conferences (pp. 649-651), National Cotton Council, Memphis, TN.

Cull, P. O., Hearn, A. B., \& Smith, R. C. (1981). Irrigation scheduling of cotton in a climate with uncertain rainfall. I. Crop water requirements and response to irrigation. Irrig. Sci., 2, 127-140. http://dx.doi.org/10.1007/BF00257975

Fernandez, C. J., McInnes, K. J., \& Cothren, J. T. (1996). Water status and leaf area production in water- and $\begin{array}{lllll}\text { nitrogen-stressed } \quad \text { cotton. } & \text { Crop } & \text { Sci., } & 36, & 1224-1233 .\end{array}$ http://dx.doi.org/10.2135/cropsci1996.0011183X003600050026x

Gerik, T. J., Oosterhuis, D. M., \& Torbert, H. A. (1998). Managing cotton nitrogen supply. Adv. Agron., 64, 115-147. http://dx.doi.org/10.1016/S0065-2113(08)60503-9

Girma, K., Teal, R. K., Freeman, K. W., Boman, R. K., \& Ruan, W. R. (2007). Cotton lint yield and quality as affected by applications of N, P, and K fertilizers. J. of Cotton Science, 11, 12-19.

Littell, R. C., Milliken, G. A., Stroup, W. W., Wolfinger, R. D., \& Schabenberger, O. (2006). SAS for Mixed Models (2nd ed.). Cary, NC: SAS Institute Inc.

Peters, G., \& Meier, S. (2010). Description of all quality parameters measured by Uster Technologies fiber and yarn testing equipment. Retrieved May 8, 2012, from http://www.uster.com/fileadmin/customer/Knowledge/Textile_Know_How/Yarn_testing/U_LabSystems_D escription_of_al_quality.pdf

Pettigrew, W. T. (2004). Moisture deficit effects on cotton lint yield, yield components, and boll distribution. Agronomy Journal, 96(2), 377-383. http://dx.doi.org/10.2134/agronj2004.0377

Potter, A. R., Atwood, J. D., \& Goss, D. W. (2001). Modeling regional and national non-point source impacts from US agriculture. ASAE Paper No. 012191. St. Joseph, Mich.: ASAE. 
Saleem, M. F., Bilal, M. F., Awais, M., Shahid, M. Q., \& Anjum, S. A. (2010). Effect of nitrogen on seed cotton yield and fiber qualities of cotton (Gossypium hirsutum L.) cultivars. The Journal of Animal \& Plant Sciences, 20(1), 23-27.

Shepherd, J. V. (1972). Standard procedures for foreign matter and moisture analytical tests used in cotton ginning research. USDA Agricultural Handbook No. 422.

Whitaker, J., R., Ritchie, G. L., Bednarz, C. W., \& Mills, C. I. (2008). Cotton subsurface drip and overhead irrigation efficiency, maturity, yield, and quality. Agron. J., 100(6), 1763-1768. http://dx.doi.org/10.2134/agronj2008.0036

\section{APPENDIX}

Cotton fiber properties determined by the AFIS and HVI

\section{AFIS parameters}

Nep: $\quad$ Total nep count per gram

Dust: $\quad$ Dust $(<500 \mu \mathrm{m})$ particle per gram

Trash: $\quad$ Trash $(>500 \mu \mathrm{m})$ particle per gram

VFM: $\quad$ Percentage of visible foreign matter by weight

L(n,w): $\quad$ Mean fiber length

SFC(n,w): Short fiber content; percentage of fibers shorter than $12.7 \mathrm{~mm}$

UQL(w): Fiber length exceeded by $25 \%$ of the fibers

Fine: $\quad$ Fiber fineness

IFC: $\quad$ Percentage of immature fibers

Mat ratio: Maturity ratio

\section{HVI parameters}

Mic: $\quad$ Micronaire, measure of fiber fineness and maturity

Mat: Maturity

UHML: $\quad$ Upper half mean length

UI: $\quad$ Uniformity index

SFI: $\quad$ Short fiber index, percentage of fibers shorter than $12.7 \mathrm{~mm}$

Rd: $\quad$ Reflectance of fibers, higher Rd values mean a higher color grade

$+\mathrm{b}$ : Yellowness of fibers

CGrd: $\quad$ Color grade, color classing parameter based on the U.S. Grade Standard (USDA)

Str: $\quad$ Strength, breaking force of a fiber bundle divided by fiber fineness

Elg: $\quad$ Elongation, breaking elongation of the fiber bundle

TrAr: $\quad$ Area of the sample covered with trash particles

TrCnt: $\quad$ Number of trash particles

\section{Copyrights}

Copyright for this article is retained by the author(s), with first publication rights granted to the journal.

This is an open-access article distributed under the terms and conditions of the Creative Commons Attribution license (http://creativecommons.org/licenses/by/3.0/). 